\title{
Enhancement or Suppression of ACE Inhibitory Activity by a Mixture of Tea and Foods for Specified Health Uses (FOSHU) That Are Marketed as "Support for Normal Blood Pressure"
}

\author{
Isao Murakami, ${ }^{1}$ Hiroyuki Hosono, ${ }^{1}$ Shigeto Suzuki, ${ }^{2}$ Junichi Kurihara, ${ }^{2}$ \\ Fumio Itagaki, ${ }^{1}$ and Machiko Watanabe ${ }^{1}$ \\ ${ }^{1}$ Division of Medical and Pharmaceutical Sciences-II, Faculty of Pharmaceutical Sciences, Teikyo University, 2-11-1, Kaga, \\ Itabashi, Tokyo 173-8605, Japan \\ ${ }^{2}$ Division of Medical and Pharmaceutical Sciences-I, Faculty of Pharmaceutical Sciences, Teikyo University, 1091-1, Suarashi, \\ Midori, Sagamihara, Kanagawa 252-0195, Japan
}

Correspondence should be addressed to Isao Murakami, mura-is@pharm.teikyo-u.ac.jp

Received 23 April 2011; Accepted 18 June 2011

Academic Editors: A. N. Assimopoulou, A. Bolognese, J.-J. Chen, and S. Vincent

Copyright (C) 2011 Isao Murakami et al. This is an open access article distributed under the Creative Commons Attribution License, which permits unrestricted use, distribution, and reproduction in any medium, provided the original work is properly cited.

\begin{abstract}
The ACE inhibitory activities of mixtures of FOSHUs (Healthya, Goma-Mugicha, Lapis Support and Ameal) were examined in order to identify any antihypertensive interactions. Among combinations of Healthya with other samples that contain active peptides, only that with Ameal was found to have no inhibitory activity. Enhanced activity was observed in 2 other mixtures. The activity of a mixture of tea polyphenols and the whey component extracted from an Ameal solution was significantly decreased, thus demonstrating that whey protein lowered the ACE inhibitory activity of Healthya. Although oral administration of tea polyphenols alone significantly decreased SBP in SHR at 2 and $4 \mathrm{hr}$, combined administration with Ameal failed to decrease SBP at the same time points. In conclusion, the simultaneous intake of tea and FOSHUs that contain active peptides might affect daily selfantihypertensive management via enhancement or suppression of ACE inhibitory activity.
\end{abstract}

\section{Introduction}

Tea polyphenols contained in green tea leaves (Camellia sinensis L.) are known to have antiviral [1], antioxidative $[2,3]$, antimutagenic [4], anticarcinogenic [5], antiobesity [6], and antihypertensive activities [7-9]. Tea leaves contain tea polyphenols such as catechins, so regular consumption of green tea is thought to be beneficial to one's health.

With rising health consciousness among consumers, particular attention has recently focused on green tea's action to counter obesity and hypertension, which are diagnostic criteria for metabolic syndrome [10]. Tea beverages that contain high levels of tea polyphenols and that are labeled "For individuals worried about body fat" are being sold in Japan as foods for specified health uses (FOSHUs).

Long-term consumption of tea has been reported to result in antihypertensive activity in spontaneously hypertensive rats (SHRs) $[7,8]$ while another study reported antihypertensive activity with a single administration of tea [9]. The antihypertensive activity of tea polyphenols is thought to occur via the inhibition of angiotensin-converting enzyme (ACE) activity [11]. Moreover, other FOSHUs, many of which have active components consisting of peptides that inhibit ACE activity, are marketed to target "individuals with high blood pressure" [12-14].

Indeed, tea beverages and FOSHUs can be readily obtained, so there may be instances in which they are consumed together. However, for individuals with high blood pressure, little is known about the antihypertensive interaction between tea and FOSHUs, which are both thought to have the same mechanisms of action.

Thus, the aim of the current study was to examine the antihypertensive interaction when a tea beverage and a FOSHU "For individuals with high blood pressure" (Goma-Mugicha, Lapis Support, and Ameal) were consumed together. 


\section{Materials and Methods}

2.1. Materials. The green tea beverage used was Healthya Green Tea (Kao Corporation, Tokyo). The 3 FOSHU products were Ameal (Calpis Co., Tokyo), which is claimed to "help maintain a normal blood pressure level" and contains Val-Pro-Pro as its active ingredient [12], Lapis Support (Tokiwa Yakuhin Co., Ltd., Yamaguchi, Japan), which has Val-Tys as its active ingredient [13], and GomaMugicha (Suntory Foods Ltd., Tokyo), which has Leu-ValTys as its active ingredient [14]. Whey protein concentrate (WPC: Protein, Easy Sports Co., Ltd., Tokyo) was also used. Polyphenon CG (green tea extract, tea polyphenol content of at least 30\%) was purchased from Mitsui Norin Co., Ltd. (Tokyo). Rabbit lung ACE was purchased from Sigma Chemical Co. (St. Louis, MO). All other chemicals were obtained from Wako Pure Chemicals Co. (Tokyo).

2.2. Preparation of Ameal. The whey fraction was used to determine the ACE inhibitory activity of Ameal. The whey fraction was obtained as follows [15]. The $\mathrm{pH}$ of Ameal was adjusted to 3.4 by adding $50 \%$ lactic acid. The Ameal was centrifuged at $6,000 \times \mathrm{g}$ for $10 \mathrm{~min}, 10 \mathrm{~N} \mathrm{NaOH}$ was added to the supernatant to raise the $\mathrm{pH}$ to 8.3 , and then the supernatant was centrifuged at $6,000 \times \mathrm{g}$ for $10 \mathrm{~min}$. The whey fraction of Ameal was used as a sample.

2.3. Assay of ACE Inhibitory Activity. ACE inhibitory activity was assayed according to the method of Suzuki et al. [16] with some modifications. Hippuryl-L-histidyl-L-leucine (Hip-His-Leu) was dissolved in $400 \mathrm{mM}$ phosphate buffer ( $\mathrm{pH}$ 8.5) containing $300 \mathrm{mM} \mathrm{NaCl}$. Next, $0.1 \mathrm{~mL}$ of $4.7 \mathrm{mM}$ Hip-His-Leu solution was mixed with $0.05 \mathrm{~mL}$ of sample solution (Healthya, Goma-Mugicha, Lapis Support, Ameal, and their mixtures) and then preincubated for $5 \mathrm{~min}$ at $37^{\circ} \mathrm{C}$. The reaction was initiated by the addition of $0.1 \mathrm{~mL}$ of ACE dissolved in distilled water $(25 \mathrm{mU} / \mathrm{mL})$, and the mixture was incubated for $30 \mathrm{~min}$ at $37^{\circ} \mathrm{C}$. After the reaction had been stopped by adding $0.3 \mathrm{~N} \mathrm{NaOH}(0.75 \mathrm{~mL}), 0.05 \mathrm{~mL}$ of $2 \% o$-phthaldialdehyde in methanol was added, the mixture was left at room temperature for $10 \mathrm{~min}$, and then $0.1 \mathrm{~mL}$ of $0.1 \mathrm{~N} \mathrm{HCl}$ was added. After incubation for $30 \mathrm{~min}$ at room temperature, the amount of liberated His-Leu was determined by measuring the fluorescent intensity of its adduct with $o$-phthaldialdehyde (excitation at $340 \mathrm{~nm}$ and emission at $455 \mathrm{~nm}$ ). The extent of inhibitory activity was calculated as follows:

$$
100-\left[\frac{B-A}{B-C} \times 100\right],
$$

where $A$ is the fluorescent intensity in the presence of ACE and ACE inhibitory component, $B$ is the fluorescent intensity without ACE inhibitory component, and $C$ is the fluorescent intensity without ACE.

Inhibition was expressed as the concentration of component that inhibits $50 \%$ of ACE activity $\left(\mathrm{IC}_{50}\right)$. One unit of ACE inhibitory activity was expressed as the potency showing 50\% ACE inhibition under these conditions and was calculated for one bottle, daily intake, or maximum dosage.
TABLE 1: ACE inhibitory activity of green tea beverage and FOSHU. ACE inhibitory activity is shown as mean $\pm \mathrm{SD}, n=6$. ${ }^{*}$ The ACE inhibitory activity is shown in relation to the concentration of tea polyphenol included in Healthya or functional component in each FOSHU.

\begin{tabular}{lc}
\hline Sample & ACE inhibitory activity $\mathrm{IC}_{50}(\mathrm{ng} / \mathrm{mL})^{*}$ \\
\hline Healthya & $64.8 \times 10^{3} \pm 7.3 \times 10^{3}$ \\
Goma-Mugicha & $19.36 \pm 4.87$ \\
Lapis Support & $76.67 \pm 11.12$ \\
Ameal & $882.70 \pm 72.70$ \\
\hline
\end{tabular}

2.4. Measurement of $\beta$-Lactoglobulin Concentrations. The concentration of $\beta$-lactoglobulin $(\beta-\operatorname{Lg})$ was measured using a FASPEK milk ( $\beta$-lactoglobulin) kit (Morinaga Institute of Biological Science, Yokohama, Japan) [17].

2.5. Animals. Male SHRs (SHR/NCrlCrlj) were purchased from Charles River Japan (Yokohama). The SHRs were kept in an air-conditioned room at $22-24^{\circ} \mathrm{C}$ with $55 \%$ humidity and a $12 \mathrm{hr}$ light-dark cycle (lights on at 8:00 AM). Food and water were freely available. After an overnight fast, $2 \mathrm{~g}$ of Polyphenon CG were dissolved in distilled water or $6 \mathrm{~mL}$ of Ameal and orally administered at a dose of $6 \mathrm{~mL} / \mathrm{kg}$ to conscious SHRs (body weight: 320-390 g, 22-25 weeks old) using a feeding needle. Following administration, systolic blood pressure (SBP) was measured every $2 \mathrm{hr}$. SBP after administration was measured by the tail-cuff method using an MK-2000 blood pressure monitor (Muromachi Kikai Ltd., Japan). The studies were performed according to the guidelines of the Animal Care and Use Committee of Teikyo University. All experiments conformed to the guidelines on the ethical use of animals, and all efforts were made to minimize both the number of animals used in the experiments and their suffering.

2.6. Statistical Analysis. Results are expressed as the mean and standard deviation (SD). The significance of differences in ACE inhibitory activity and SBP was analyzed using the Dunnett test or Tukey test.

\section{Results and Discussion}

3.1. Effects of Several Mixtures of Tea and FOSHU on ACE Inhibitory Activity. ACE inhibitory activity $\left(\mathrm{IC}_{50}\right)$ was detected in all samples $\left(64.8 \times 10^{3} \pm 7.3 \times 10^{3} \mathrm{ng} / \mathrm{mL}\right.$, $19.36 \pm 4.87 \mathrm{ng} / \mathrm{mL}, 76.67 \pm 11.12 \mathrm{ng} / \mathrm{mL}$, and $882.70 \pm$ $72.70 \mathrm{ng} / \mathrm{mL}$, resp.) (Table 1). When Healthya was mixed with one of the FOSHUs, the two mixtures of Healthya plus Goma-Mugicha and Healthya plus Lapis Support had enhanced inhibitory activity. The mixture of Healthya plus Ameal did not have enhanced inhibitory activity. The ACE inhibitory activity shown in Figure 1 was calculated as $\mathrm{IC}_{50}$ based on the amount of functional components included in each food product for specified health uses.

3.2. Effects of a Mixture of Tea and Whey Protein on ACE Inhibitory Activity. In order to determine why the ACE 


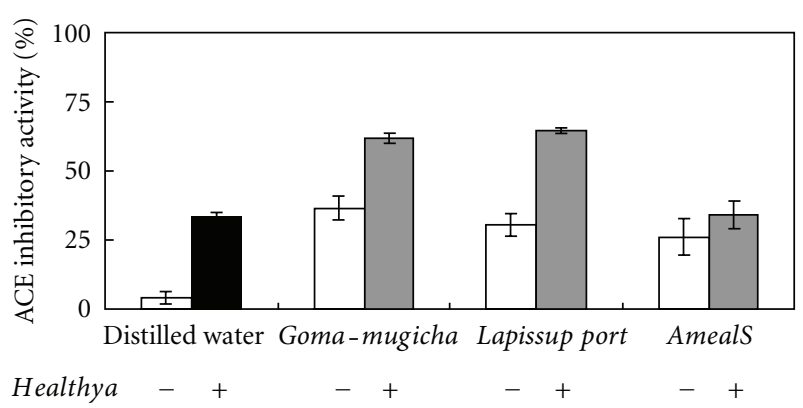

Figure 1: ACE inhibitory activity of mixtures of Healthya and FOSHU. Activity of Healthya with respect to converting $32.5 \mathrm{mg} / \mathrm{mL}$ of tea polyphenols (black square) and ACE inhibitory peptides in a FOSHU (white square: Goma-Mugicha conversion of $10 \mathrm{ng} / \mathrm{mL}$ Leu-Val-Tys, Lapis Support conversion of $38 \mathrm{ng} / \mathrm{mL}$ Val-Tys, and Ameal conversion of $445 \mathrm{ng} / \mathrm{mL}$ Val-Pro-Pro) or a mixture of Healthya and FOSHU (gray square). Data are expressed as mean \pm $\mathrm{SD}, n=3$.

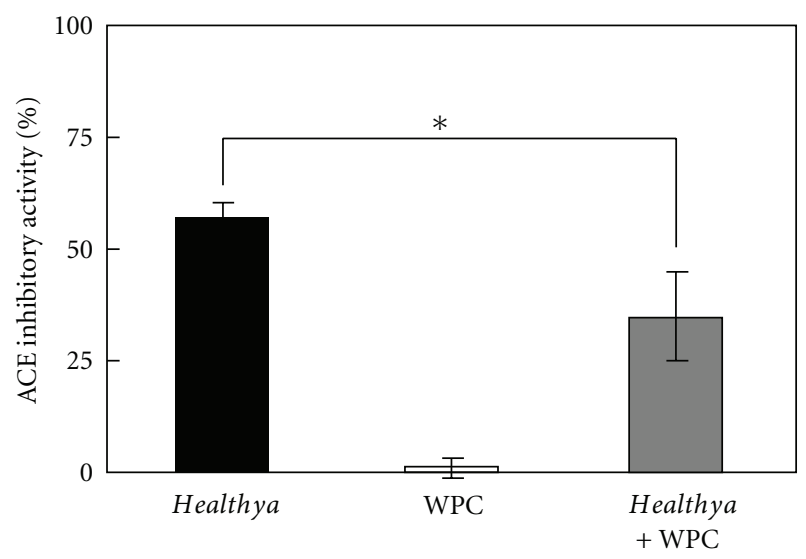

FIGURE 2: ACE inhibitory activity of Healthya with or without WPC. Activity of Healthya with respect to converting $65 \mathrm{mg} / \mathrm{mL}$ of tea polyphenols (black square), $3 \mathrm{mg} / \mathrm{mL}$ WPC (white square), or a mixture of Healthya and WPC (gray square). Data are expressed as mean $\pm \mathrm{SD}, n=3$. ( ${ }^{*} P<0.05$, Tukey test $)$.

inhibitory activity of a mixture of Healthya and Ameal was not enhanced, the elemental composition of each FOSHU was investigated. The whey fraction used in this experiment was in fact extracted from an Ameal solution (GomaMugicha and Lapis Support do not contain any ingredients that originate from milk). Healthya that was prepared to determine the $\mathrm{IC}_{50}$ was mixed with $3 \mu \mathrm{g} / \mathrm{mL}$ WPC, and the mixture's rate of ACE inhibitory activity was measured. The concentration of $\beta$-lactoglobulin, the main component of whey protein [18], was $1.28 \mu \mathrm{g} / \mathrm{mL}$ in $3 \mu \mathrm{g} / \mathrm{mL}$ WPC and $18.6 \mu \mathrm{g} / \mathrm{mL}$ in the whey fraction of Ameal (concentration of $\mathrm{IC}_{50}, 445 \mathrm{ng} / \mathrm{mL}$ Val-Pro-Pro). WPC $(3 \mu \mathrm{g} / \mathrm{mL}$, as whey) and Healthya (as tea polyphenol) were used for measurement. Examination of the ACE inhibitory activity of a mixture of whey component and tea polyphenols revealed a significant decrease in the rate of ACE inhibitory activity of Healthya $(56.9 \pm 3.2 \%)$ as a result of the addition of $3 \mu \mathrm{g} / \mathrm{mL}$ WPC

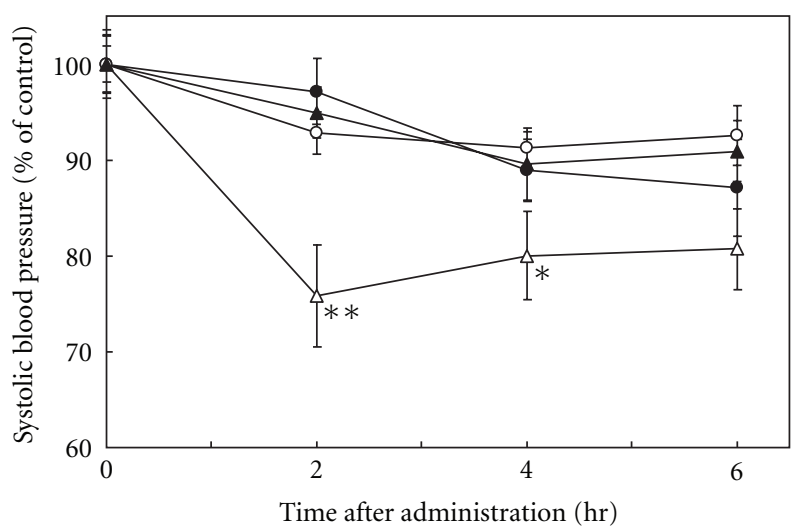

FIgURE 3: Time course of hypotensive activity after oral administration of tea polyphenols (Polyphenon CG) to SHRs. Distilled water (control); $\bigcirc$, Ameal; $\Delta$, Polyphenon $C G$ in Ameal; $\triangle$, Polyphenon $C G$ in distilled water. The vertical axis represents changes in SBP from time zero. Changes in SBP from time zero are expressed as the mean $\pm \mathrm{SD}, n=7$. The baseline SBP before administration was $198.2 \pm 3.0 \mathrm{mmHg}$. $\left({ }^{*} P<0.05,{ }^{* *} P<0.01\right.$ compared to distilled water, Dunnett's test.)

$(34.9 \pm 9.8 \%: P<0.05)$ (Figure 2), thus demonstrating that whey protein lowered the rate of ACE inhibitory activity of Healthya.

3.3. Effects of Tea Polyphenols and Ameal on Antihypertensive Activity in SHRs. To evaluate the antihypertensive activity of the interaction of tea polyphenols and Ameal, the SBP of SHRs was measured after a single oral administration. The baseline SBP before administration was $198.2 \pm 3.0 \mathrm{mmHg}$. Tea polyphenols (polyphenon CG, $2 \mathrm{~g} / \mathrm{kg}$ body weight) significantly lowered SBP 2 and $4 \mathrm{hr}$ after administration (155.4 \pm $8.4 \mathrm{mmHg}$ and $163.8 \pm 7.6 \mathrm{mmHg}$, resp.) in comparison to distilled water $(195.3 \pm 6.7 \mathrm{mmHg}$ and $178.8 \pm 5.8 \mathrm{mmHg}$, resp.) $(P<0.05)$. However, oral administration of polyphenon $C G$ and Ameal failed to decrease SBP $(178.9 \pm 4.7 \mathrm{mmHg}$ and $169.2 \pm 8.3 \mathrm{mmHg}$, resp.) at the same times (Figure 3). Therefore, combined administration of Polyphenon CG with Ameal appears to attenuate antihypertensive activity by interacting with the whey protein in the Ameal solution. Though possible mechanisms of the interaction of tea and milk protein have been discussed in previous reports [1921], the actual mechanism is still not clear

In this study, markedly larger amounts of tea catechins than humans would normally be consumed in typical foods that were administered to SHRs, and this study examined the interaction of these catechins. While many health foods contain much smaller amounts of substances than were used in the current experiments, numerous products are being sold in formulations with active components in higher concentrations than that would normally be consumed. In addition, the amount of health foods consumed is substantial when individuals have a strong predilection toward selfmedication. Many such individuals will presumably consume numerous types of health foods at the same time. Accordingly, large quantities of tea catechins were used in 
the current study, and the consumption of such amounts is indeed a possibility.

Moreover, this study focused on blood pressure, which was found to be affected soon after administration [9], but interaction between tea catechins and whey protein attenuated the activity of the two, much like other types of activity (e.g., antiviral, antioxidative, antimutagenic and anticarcinogenic, and antiobesity activity) are attenuated. Based on results of the current study, consuming multiple health foods at the same time enhanced the activity of individual components in some instances. That said, the results also suggested that such consumption led to interactions, diminishing the effectiveness of some of the components of these foods.

\section{Conclusion}

The findings of the present study suggest for the first time that interaction between tea and milk protein may attenuate antihypertensive activity and that the simultaneous intake of tea and FOSHUs that contain active peptides might affect daily self-antihypertensive management via the enhancement or suppression of ACE inhibitory activity.

\section{References}

[1] S. Shiota, M. Shimizu, T. Mizushima et al., "Marked reduction in the minimum inhibitory concentration (MIC) of $\beta$ - lactams in methicillin-resistant Staphylococcus aureus produced by epicatechin gallate, an ingredient of green tea (Camellia sinensis)," Biological and Pharmaceutical Bulletin, vol. 22, no. 12, pp. 1388-1390, 1999.

[2] T. Okuda, Y. Kimura, T. Yoshida, T. Hatano, H. Okuda, and S. Arichi, "Studies on the activities of tannins and related compounds from medicinal plants and drugs. I. Inhibitory effects on lipid peroxidation in mitochondria and microsomes of liver," Chemical and Pharmaceutical Bulletin, vol. 31, no. 5, pp. 1625-1631, 1983.

[3] A. Rietveld and S. Wiseman, "Antioxidant effects of tea: evidence from human clinical trials," The Journal of Nutrition, vol. 133, no. 10, pp. 3285S-3292S, 2003.

[4] T. Kada, K. Kaneko, S. Matsuzaki, T. Matsuzaki, and Y. Hara, "Detection and chemical identification of natural bioantimutagens : a case of the green tea factor," Mutation Research/Fundamental and Molecular Mechanisms of Mutagenesis, vol. 150, no. 1-2, pp. 127-132, 1985.

[5] H. Fujiki, M. Suganuma, S. Okabe et al., "Cancer inhibition by green tea," Mutation Research/Fundamental and Molecular Mechanisms of Mutagenesis, vol. 402, no. 1-2, pp. 307-310, 1998.

[6] T. Murase, A. Nagasawa, J. Suzuki, T. Hase, and I. Tokimitsu, "Beneficial effects of tea catechins on diet-induced obesity: stimulation of lipid catabolism in the liver," International Journal of Obesity, vol. 26, no. 11, pp. 1459-1464, 2002.

[7] M. A. Potenza, F. L. Marasciulo, M. Tarquinio et al., "EGCG, a green tea polyphenol, improves endothelial function and insulin sensitivity, reduces blood pressure, and protects against myocardial I/R injury in SHR," American Journal of Physiology, vol. 292, no. 5, pp. E1378-E1387, 2007.

[8] H. Negishi, J.-W. Xu, K. Ikeda, M. Njelekela, Y. Nara, and Y. Yamori, "Black and green tea polyphenols attenuate blood pressure increases in stroke-prone spontaneously hypertensive rats," Journal of Nutrition, vol. 134, no. 1, pp. 38-42, 2004.

[9] Y. Sagesaka-Mitane, T. Sugiura, Y. Miwa, K. Yamaguchi, and K. Kyuki, "Effect of tea-leaf saponin on blood pressure of spontaneously hypertensive rats," Yakugaku Zasshi, vol. 116, no. 5, pp. 388-395, 1996.

[10] K. G. M. M. Alberti, P. Zimmet, and J. Shaw, "The metabolic syndrome-a new worldwide definition," The Lancet, vol. 366, no. 9491, pp. 1059-1062, 2005.

[11] L. T. Skeggs, J. R. Khan, and N. P. Shumway, "Preparation and function of the hypertensin-converting enzyme," The Journal of Experimental Medicine, vol. 103, no. 3, pp. 295-299, 1956.

[12] Y. Nakamura, N. Yamamoto, K. Sakai, and T. Takano, "Antihypertensive effect of sour milk and peptides isolated from it that are inhibitors to angiotensin I-converting enzyme," Journal of Dairy Science, vol. 78, no. 6, pp. 1253-1257, 1995.

[13] T. Kawasaki, E. Seki, K. Osajima et al., "Antihypertensive effect of Valyl-Tyrosine, a short chain peptide derived from sardine muscle hydrolyzate, on mild hypertensive subjects," Journal of Human Hypertension, vol. 14, no. 8, pp. 519-523, 2000.

[14] D. Nakano, K. Ogura, M. Miyakoshi et al., "Antihypertensive effect of angiotensin I-converting enzyme inhibitory peptides from a sesame protein hydrolysate in spontaneously hypertensive rats," Bioscience, Biotechnology and Biochemistry, vol. 70, no. 5, pp. 1118-1126, 2006.

[15] Y. Nakamura, N. Yamamoto, K. Sakai, A. Okubo, S. Yamazaki, and T. Takano, "Purification and characterization of angiotensin I-converting enzyme inhibitors from sour milk," Journal of Dairy Science, vol. 78, no. 4, pp. 777-783, 1995.

[16] T. Suzuki, N. Ishikawa, and H. Meguro, "Angiotensin Iconverting enzyme inhibiting activity in foods (studies on vasodepressive components in foods. part I)," Nippon Nogeikagaku Kaishi, vol. 57, no. 11, pp. 1143-1146, 1983.

[17] Y. Watanabe, K. Aburatani, T. Mizumura et al., "Novel ELISA for the detection of raw and processed egg using extraction buffer containing a surfactant and a reducing agent," The Journal of Immunological Methods, vol. 300, no. 1-2, pp. 115123, 2005.

[18] R. Jenness, "Inter-species comparison of milk proteins," in Developments in Dairy Chemistry, P. F. Fox, Ed., pp. 87-114, Applied Science Publisher, London, UK, 1982.

[19] M. G. L. Hertog, P. M. Sweetnam, A. M. Fehily, P. C. Elwood, and D. Kromhout, "Antioxidant flavonols and ischemic heart disease in a Welsh population of men: the Caerphilly study," American Journal of Clinical Nutrition, vol. 65, no. 5, pp. 14891494, 1997.

[20] A. Papadopoulou and R. A. Frazier, "Characterization of protein-polyphenol interactions," Trends in Food Science and Technology, vol. 15, no. 3-4, pp. 186-190, 2004.

[21] K. J. Siebert, N. V. Troukhanova, and P. Y. Lynn, "Nature of polyphenol-protein interactions," Journal of Agricultural and Food Chemistry, vol. 44, no. 1, pp. 80-85, 1996. 

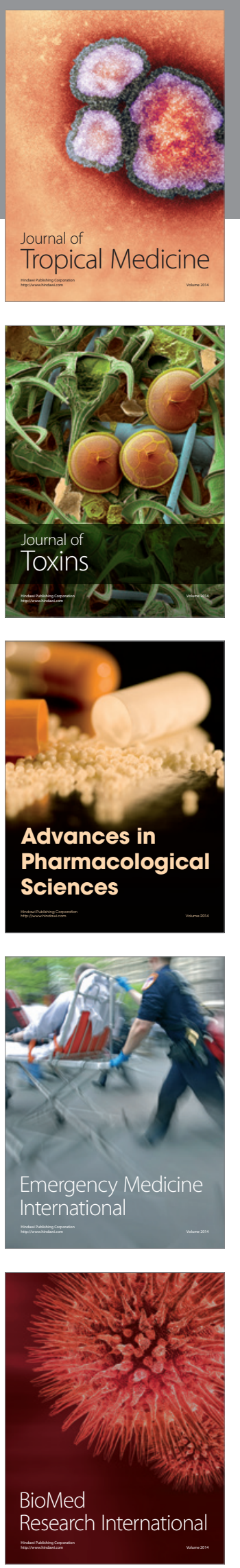
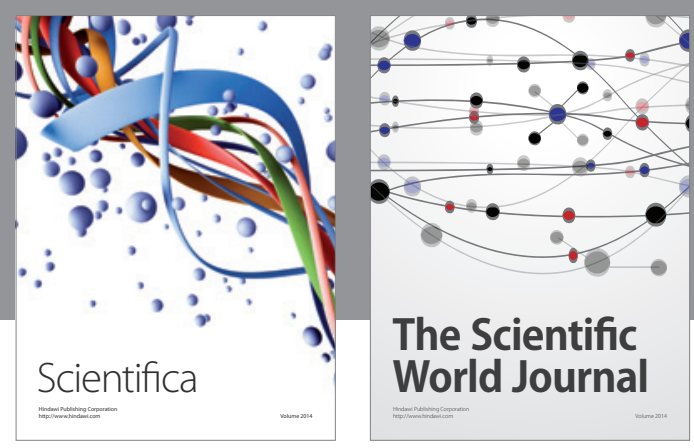

The Scientific World Journal
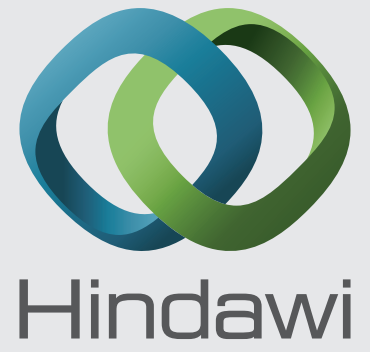

Submit your manuscripts at

http://www.hindawi.com
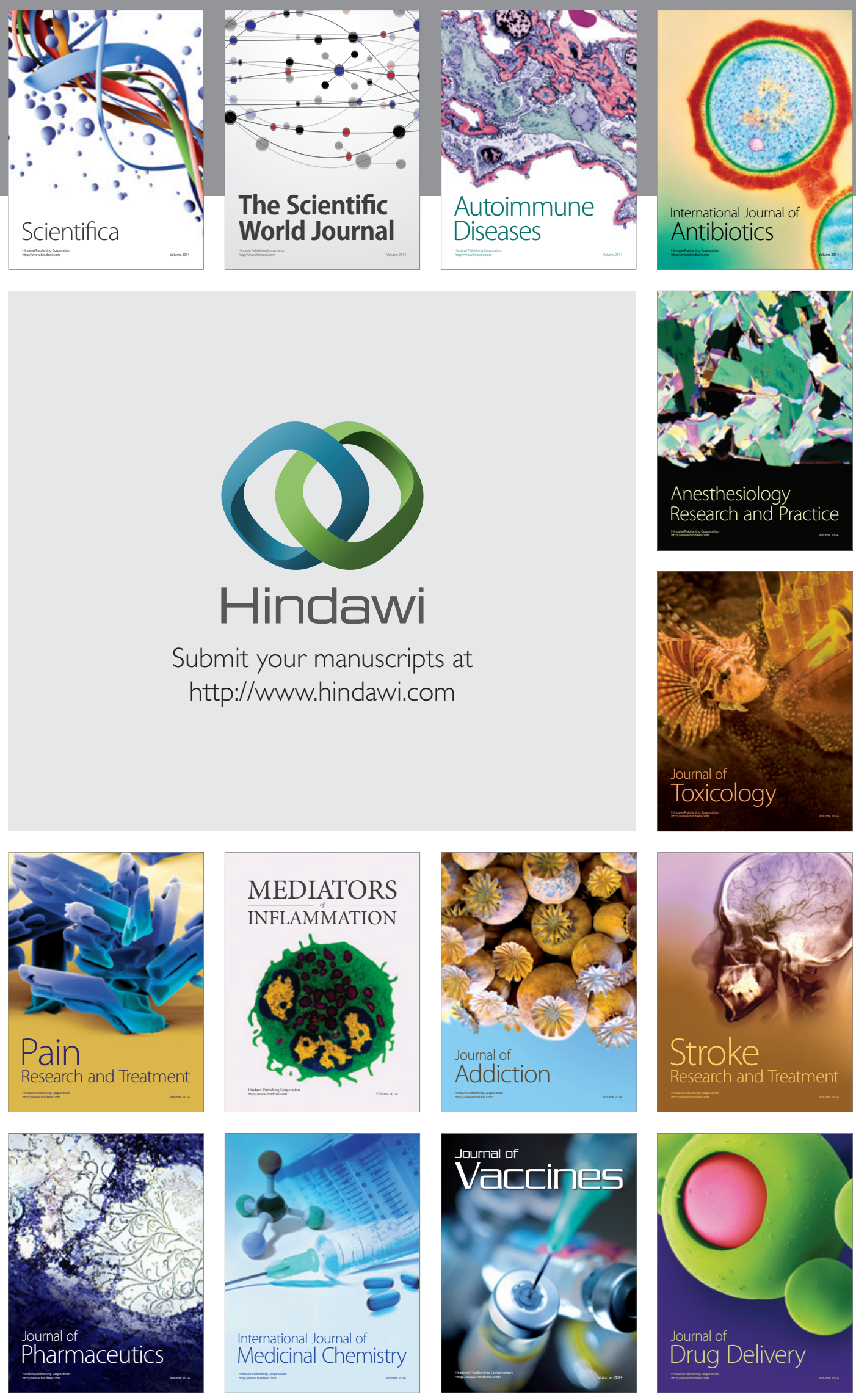